\title{
"What Guarantees Do We Have?" Legal Tolls and Persistent Impunity for Feminicide in Guatemala
}

\author{
Shannon Drysdale Walsh \\ Cecilia Menjivar
}

\begin{abstract}
Guatemala has one of the highest levels of killings of women and impunity for violence against women in the world. Despite laws created to protect women, Guatemala, like other countries, generally fails at implementation. This article examines justice system obstacles in contemporary Guatemala to processing cases of feminicide-killings of women because they are women in a context of impunity - comparing two recent feminicide cases. It argues that the sociopolitical context in Guatemala, including structural violence, widespread poverty, inequality, corruption, and normalization of gender violence against women, generates penalties, or "legal tolls," that are imposed on victims' families and contribute to impunity through undermining victims' attempts to navigate the justice system. The analysis focuses on the tolls of fear and time: the need to overcome fear of retaliation and the extraordinary time and effort it takes to do so in a corrupt and broken system.
\end{abstract}

T mpunity has become a widespread problem in Latin America, especially for crimes against women. Despite grassroots and international success in pressuring for and strengthening women's rights laws, a wide gulf remains between the laws on the books and law in practice. Women's participation as democratic citizens is undermined in contexts of widespread crime and impunity. Guatemala in particular has been called, and remains, a "killer's paradise," with one of the highest levels of homicides of women and a paltry 1 to 2 percent conviction rate (Portenier 2007; U.S. Department of State 2012). Haunting similarities have been observed between signs of sexualized torture found on female victims today and methods of torture used against women during the genocide and civil war years (Sanford 2008).

Despite laws on the books created to protect women, Guatemala lacks the rule of law that translates these rights into legal action. This article analyzes the broader context that shapes justice system obstacles to implementing laws on violence

Shannon Drysdale Walsh is an assistant professor and McKnight Land-Grant Professor in the Department of Political Science at the University of Minnesota, Duluth. shannondwalsh@ gmail.com. Cecilia Menjívar is Foundation Distinguished Professor of Sociology at the University of Kansas. menjivar@ku.edu. Authors are listed in reverse alpha order; however, both contributed equally to this article. 
against women and processing cases of feminicide-killings of women because they are women in a context of impunity-in contemporary Guatemala.

The right to legal protection from and prosecution of murder is one of the most basic foundations of the rule of law in a democracy. With regard to women in particular, Htun and Power $(2006,85)$ aptly note that "people who are concerned about gender equality must ... turn their eyes to the state: its laws and policies constitute a significant force inhibiting, or accelerating, social transformation." Legal rights "seek to reshape the distribution of power in a society: they shift rights/freedoms and duties/constraints away from where the market or the distribution of coercive resources might otherwise deposit them" (Brinks 2008, 3).

In many countries, widespread normative biases exist against implementing laws that address women's rights (Eisenberg 2011). Extant research has suggested various reasons for the gap between the law on the books and law in practice. The dominant rationale is that human rights laws encounter resistance when domestic actors perceive them as "external" to local value systems (e.g., Kent 2007; Liaw 2008). However, laws punishing murder-even those with additional penalties for vulnerable groups-are universal. So we examine alternative explanations for a fundamental question: what explains the gap between formal law and implementation, specifically with regard to feminicide? This study sheds light on how a generalized context of multiple forms of violence informs the "law in between"; the justice system and those in charge of implementing laws (Jenness and Grattet 2005).

When the rule of law is functioning properly, formal laws are implemented evenly, regardless of the class, status, or relative power of the parties involved (O'Donnell 2004). In such a state, the burden of implementation is on the state, not on victims or families. Prior research explains that in contexts of high impunity, "legal tolls" are imposed on victims and their families as they attempt to advance cases through the justice system (Brinks 2008). As the system extracts "tolls" from these families along the way, cases are dropped — especially for the poor and marginalized who cannot afford to pay for them. This study adds to this framework by articulating and defining two types of tolls that are particularly prevalent in Guatemala: the toll of overcoming fear in a context where protection is lacking and the toll of time and effort in a legal system that is a labyrinth of bureaucracy and discrimination. We also extend the concept of legal tolls by demonstrating that these tolls are not only classed but also gendered, especially in cases of violence against women.

Guatemala's socioeconomic and political context includes widespread poverty, inequality, corruption, and normalization of violence against women (Menjívar 2011; Walsh and Menjívar 2016). Claimants living in conditions of poverty, structural violence, and inequality have fewer resources to defend themselves from retaliation. In a system with a well-earned reputation for corruption (Boche 2015; Peacock and Beltrán 2003), claimants must spend time and effort mitigating the potential impacts of corruption that could undermine the advancement of their cases. They must also navigate a justice system that has failed to address violence against women and has institutionalized it as normal. 
We argue that a context of normalized gender violence imposes the extraction of specific gendered and classed legal tolls before and after women are murdered, as it shapes the functioning of the justice system. When the justice system is dysfunctional, the burden of pursuing justice is placed on victims and their families, but these tolls are so costly that it increases the likelihood that families will stop pursuing it and that cases will be dropped, resulting in persistent impunity. We argue that this context results in a gendered and classed subversion of the rule of law that makes it extraordinarily difficult for victims and families to get cases of violence against women processed through the justice system, especially cases involving women and the poor.

Research and popular media tend to focus on "machista culture," or the behavior of individual men, to explain the phenomenon of feminicide (McCarthy 2015; Volk and Schlotterbeck 2007). However, this study sets aside these individual-level explanations to reveal how the broader context in which laws are passed sustains impunity by posing obstacles to victims and their families as they navigate the justice system. Other scholarship focuses on analyzing the failure of the laws themselves (Gasman and Álvarez 2016). We take a step beyond this and analyze how laws designed to protect women from murder operate in practice. Following other work in this vein (Brinks 2008; Moser 2001), we challenge institutional approaches that limit analyses to formal rules or assume similar results across varying contexts. In doing so, this study contributes to scholarship explaining legal effectiveness, or the "responsiveness of the legal system to the claim of a right" (Brinks 2008, 18), by identifying key contextual factors and the burdens they place on victims and their families. It also contributes to a broader understanding of the obstacles to implementation in a corrupt system in a highly unequal context along the lines of gender and social class.

This article compares two recent cases of feminicide in Guatemala to identify enduring obstacles to effectively processing these cases in general. We ask readers to keep in mind that both are "best-case scenarios" that should easily glide through the justice system because of the preponderance of evidence, as well as families' having found competent assistance through a local organization to help process the cases. So the many difficulties these families have faced are less extreme in many ways than the majority of cases with less evidence and a lack of resources and assistance. These accounts reveal what happens when claimants do not give up, which helps to illuminate why most claimants do give up.

This article contributes to the literature on feminicide in Latin America by focusing on case studies of victim families, in their voices, and revealing their experiences, as they interact with the justice system. Past research has connected high levels of feminicide to high levels of discrimination, poverty, and negative attitudes toward women (Prieto-Carrón et al. 2007). This article advances this literature by demonstrating how the normalization of violence against women increases risks that women will be murdered, and also increases the probability that perpetrators will not be held accountable.

Guatemala is not unique in its lack of implementation of laws on violence against women. As with many laws across the globe that protect women's rights, 
there is a persistent gap between the law on the books and law in practice (Eisenberg 2011). Laws with additional penalties for feminicide exist in 11 countries in Latin America: Bolivia, Chile, Colombia, Costa Rica, Ecuador, El Salvador, Guatemala, Honduras, Mexico, Nicaragua, and Venezuela (MESECVI 2014). In addition, all Latin American countries are signatories to the United Nations Convention on the Elimination of all Forms of Discrimination Against Women and the Inter-American Convention on the Prevention, Punishment and Eradication of Violence Against Women (Convention Belém do Pará).

Yet despite these legal advances, recent reports of particularly brutal murders and widespread impunity have appeared in several of these countries, including Guatemala, El Salvador, Honduras, and Nicaragua (Fregoso and Bejarano 2010; Walsh and Menjívar 2016; MESECVI 2014). Thus, this examination has applicability beyond the Guatemalan case to other similar contexts. Our analysis highlights the gendered and classed nature of these killings, which often exhibit signs of "overkill," as Torres (2005) characterizes the brutal killings of women in Guatemala. By understanding Guatemala's failure to implement laws addressing different forms of violence against women, this study identifies factors that contribute to impunity and, by focusing on the "law in between" (Jenness and Grattet 2005), explains the persistent gap between the law on the books and the law in practice.

\section{Legal Tolls, Feminicide, AND THE RULE OF LAW}

We draw on Dan Brinks's 2008 conceptualization of legal tolls to help explain impunity for killings of women. Legal tolls are a burden on victims that occurs

when the system imports extralegal particularistic conditions, as they all do to one degree or another.... [In this situation,] laws and legal instances work ... like toll barriers ... and become obstacles before which one must surrender some toll or be refused passage.... These tolls could be cash for bribes or high-priced legal representation or less tangible means of exchange like social status or personal connections. (Brinks 2008, 20)

Brinks highlights the impact of social marginalization on the rule of law. He argues that tolls are systematically exerted on the poor in unequal societies like Guatemala. We extend this argument and demonstrate that tolls are related to gender in addition to class, and that these tolls are more pronounced in a context that normalizes various forms of violence in the lives of women. We focus on the tolls of fear and time that perpetuate the lack of rule of law in Guatemala: the need to overcome fear of retaliation and the extraordinary time and effort it takes to navigate the justice system. In a context that necessitates the payment of tolls, the inability of women and the poor to do so becomes an obstacle to effectively utilizing the justice system before or after murders take place, which contributes to impunity and helps explain the gap between the law on the books and the law in practice. 
This study uses two terms to refer to killings of women: femicide and feminicide. The term femicide is used in formal law and statistical data to refer to killings of women for any reason, or because they are women (Radford and Russell 1992). In Guatemala, as well as in other countries, "femicide" laws add special penalties to cases of killings of women where there is evidence of misogyny as a motive. The term feminicide (feminicidio), on the other hand, was introduced by Latin American feminists to describe the escalating phenomenon of gender-based killings of women that occur in a context of impunity and are committed with high levels of brutality (Lagarde 2006; see also Carey and Torres 2010; Sanford 2008). This concept not only conveys the killings of women because they are women but also captures analytically the responsibility of the state, "whether through omission, negligence or collusion" (Lagarde 2006). Lagarde expands the concept of femicide using a feminist theoretical lens to note that feminicide "occurs when the historical conditions generate social practices that allow for violent attempts against the integrity, health, liberties, and lives of girls and women" (2010, xvi). Thus we use femicide when describing laws and statistics on killings of women, because this is the term used in official documents; we use feminicide as we analyze the state's actions.

Guatemala has made legal and institutional advances that ostensibly aim to improve responsiveness to feminicide and other forms of violence against women, but there have also been institutional setbacks and many obstacles to implementation. In 2006, Guatemala created a special public prosecutor's office for crimes against women. On May 2, 2008, Guatemala passed the Law Against Femicide and Other Forms of Violence Against Women (Law No. 22-2008). This law enabled the application of additional penalties if murders were classified as femicide. Specialists on crimes against women work in the public prosecutor's office (the Fiscalia de la Mujer in the Ministerio Público). In 2012, with help from the Spanish International Cooperation Agency, the police established a unit focused on investigating femicides in the Department of Crimes Against Life (Unidad de Femicidios in Delitos Contra la Vida).

The principal women's policy agency, SEPREM (the Presidential Secretariat for Women), was created to monitor and strengthen laws addressing women's issues. However, a major setback was that President Otto Pérez Molina (2012-15) reduced its funding and removed many feminists from this office in 2012 (Interview, women's rights advocates 2014). As of fall 2014, there were femicide courts in 8 out of 22 departments (or provinces). ${ }^{1}$ In addition to the Femicide Law, Guatemala passed the Law to Prevent, Punish, and Eradicate Intra-Familiar Violence (Law No. 97-1996) on November 28, 1996. This law only indirectly addresses violence against women, as it applies only when violence occurs in the context of intrafamiliar violence and it does not mention violence against women explicitly. This law provides a legal mechanism for obtaining protection orders (restraining orders). (See the appendix for details about laws addressing violence against women in Guatemala.)

Despite these advances in creating laws and even institutions to implement them, state responsiveness to violence against women is still very weak. A debilitat- 
ing sense of insecurity defines public and private life for most women in Guatemala. The disjointed reality of institutional advances, coupled with persistent shortcomings in the rule of law, is a broader trend in Latin America (Brinks 2012; Walsh 2008). Thus, in spite of Guatemala's impressive institutional advances on paper and in the bureaucracy in the past several years, impunity for crimes against women persists. What explains this incongruity? What explains this gap between the law on the books and the law in practice?

It has been argued that it is normal for women's rights reforms to encounter barriers to achieving tangible successes (e.g., Arbuckle 1996; Liaw 2008; Eisenberg 2011). Laws on the books often fail to translate into "law in action," a problem also known as the "divergence between written law and "living law"' (Ellickson 1991; Macaulay 2005, 383 for "living law"). This divergence is even more pronounced with regard to international human rights laws, in which domestic actors may perceive these laws as "external" to local value systems (Kent 2007), as the case of Guatemala may indicate. Many scholars argue that this "norm externalization" contributes to the gap between the law on the books and the application of the law (e.g., Liaw 2008).

However, failure to prosecute feminicide is not merely a problem of norm externalization. Arguably, the norm penalizing murder is universal, but the norm penalizing the murder of women — or at least the violence that usually precedes itis not. While these norms are important, the context in which they are embedded is equally so. This context includes structural violence, poverty, inequality, and corruption, which exacerbate the normalization of violence against women and inform practices, views, and attitudes in the "law in between" where laws are implemented (Jenness and Grattet 2005). The lack of implementation of the femicide laws demonstrates that "drafting and enacting a new law is one thing, implementing it is another" (Dietrich and Kvatskhava 2002).

Guatemala has a socioeconomic and political context that generates gendered and classed justice system failures and "legal tolls," including widespread poverty, inequality, corruption, and normalization of violence against women (Menjívar 2011; Walsh and Menjívar 2016; Boche 2015). It is one of the most unequal countries in Latin America, in terms of both gender and social class (UNDP 2013). Although it has a GDP per capita that is comparable to that of Costa Rica, the majority of Guatemalans live in grinding poverty (IMF 2014).

The insidious nature of widespread poverty and profound inequality is captured well by the concept of structural violence (Farmer 2004). Johan Galtung $(1969,171)$ laid the foundation for this concept, noting that structural violence is "built into the structure and shows up as unequal power and consequently as unequal life chances." Structural violence in Guatemala creates conditions for exploitation and corruption and a disregard for the needs of women and the poor, who find multiple obstacles or tolls as they navigate bureaucracies in their search for protection and justice. Structural violence not only affects different levels and types of direct violence against women, but makes women more vulnerable and makes it less likely that the state will be responsive (Walsh and Menjívar 2016). The legal 
tolls of overcoming fear and paying in time and effort in order to process cases of violence against women reinforce inequality through the justice system.

We argue that there is a gendered and classed lack of rule of law that has become institutionalized in Guatemala. The "rule of law" is a disputed term, but its minimal meaning is that whatever law exists is "written down ... promulgated by an appropriate authority ... and fairly applied by relevant state institutions" (O’Donnell 2004, 1). Fair application means applying consistent legal (formal and transparent) rules by appropriate authorities across equivalent cases without taking into consideration the status, class, or relative power of the parties involved (O'Donnell 2004). In a context such as Guatemala, where violence and multiple forms of inequality in the lives of women are normalized, the ways that the rule of law is subverted increase impunity for killings of women.

Formal institutional rules require that justice system officials operating in the "law in between" (Jenness and Grattet 2005) — that is, the police, prosecutors, and judges in Guatemala-investigate and prosecute murder cases. However, the commonly understood reality in the justice system is that victims must network (through informal channels) outside of the justice system to have any hope whatsoever of getting a case processed. Women (while they are still alive) and the poor (who may be families of feminicide victims) are less able to network due to their relative lack of social and economic power compared to aggressors (who may also be poor but are generally male). The patterns of the justice system's subverting rather than delivering justice for women and the poor have become so widespread and systematic that they neatly conform to the defining features of "informal institutions." As explained by Helmke and Levitsky, these are "socially shared rules, usually unwritten, that are created, communicated, and enforced outside officially sanctioned channels" $(2006,5)$. Furthermore, O’Donnell notes that

the set of informal rules that constitute an informal institution is common knowledge; that is, each actor knows the rules and knows that everyone else, in the relevant context of interaction, also knows the same rules. As a consequence, there exists a generalized expectation that "everyone" will follow the rules and that, in the case of failure to do so, some kind of punishment or ill will follow. (2006, 206, emphasis in original)

O'Donnell (2006) adds that even though these rules may not be transparent, they are well known to the relevant actors. When informal institutions subvert laws and legal rules, they undermine the rule of law.

The legal tolls of overcoming fear and expending time and effort have become informal institutions in Guatemala. In this context, everyone "knows" that facing threats without protection, paying bribes, and begging and pressuring for justice are expected, even in murder cases. The behavior patterns and practices of actors in the Guatemalan justice system may be categorized as "competing informal institutions" that "structure actors' incentives in ways that are incompatible with the formal rules" (Helmke and Levitsky 2006, 15). These informal institutions have more influence over behavior than the formal law in Guatemala. In this context, laws are 
a necessary but not sufficient condition for implementation, but justice system actors subvert them with longstanding and well-understood practices, so that normalized violence in the lives of women permeates justice system institutions. We argue that it is not just the widespread lack of rule of law that causes impunity for violence against women, but that the broader sociopolitical and economic context imposes the extraction of specific gendered and classed legal tolls before and after women are murdered.

\section{DATA AND Methods}

We selected Guatemala using the "extreme case" method, which focuses on cases with extreme outcomes, such as notable failures (Gerring 2007, 101). The dynamics of the justice system in Guatemala parallel other countries with a widespread lack of rule of law and low prosecution rates for killings of women, such as El Salvador and Honduras. Thus, the forces we unveil not only apply to these neighboring countries but could shed light on obstacles to justice for women in countries with high feminicide rates and persistent impunity in other regions of the world.

Furthermore, case studies are particularly useful in identifying causal mechanisms (George and Bennett 2005) that help explain the connection between causal or explanatory variables and their effects. We focus on the "legal tolls" of fear and time and effort spent in seeking justice as causal mechanisms rooted in a broader context of normalized violence in the lives of women. The imposition of these tolls helps explain the correlation between lack of rule of law and lack of reporting and follow-through by victims and their families, which, in turn, contributes to impunity.

We examine the experiences of two families in depth because their accounts reveal key details about the obstacles that individuals and families face when trying to navigate the justice system, even in the "best case scenario." Presenting only two cases enables us to deepen our analysis and reveal important intricacies of how individuals navigate the justice system, and to include the viewpoints of family members who are socially positioned differently. These families' experiences in the justice system are typical, even though they are outliers in their attempts to navigate it. Their stories reveal what happens when claimants do not give up. They demonstrate the problems that victims' families face even when they obtain assistance and accompaniment with their cases (Interview, individual working in a local organization 2015). ${ }^{2}$ Both cases had the advantage of relatively clear evidence. Thus these accounts reveal the profound and widespread problems of the Guatemalan justice system, even with cases that are clear-cut and families that have accompaniment. While few families are able to access accompaniment services, they were created to reduce impunity, and the fact that families need and seek them is an indicator of the potential obstacles they foresee. Our in-depth focus on two cases contributes methodologically and highlights the richness of in-depth case analysis.

Drawing on in-depth interviews by Shannon Drysdale Walsh, we analyze the interactions between two families and the Guatemalan justice system. Walsh con- 
ducted in-depth interviews with two families; interviews cited in the text were selected from a series of 34 interviews that Walsh conducted in fall 2014 and summer 2015. In addition, she accompanied one of these families as they attended meetings and navigated the justice system in Guatemala.

María's family had just fled their neighborhood, and their case was being initiated in the court system when Walsh conducted a lengthy open-ended interview, with a follow-up interview nine months later. Rosa's family was pressuring justice system officials to gather evidence to initiate their case when Walsh conducted several lengthy open-ended interviews with them. Walsh accompanied them to several meetings with officials in the justice system and civil society organizations over a two-week period and followed up with interviews nine months later. Both families were getting assistance from a civil society organization in Guatemala when they heard that Walsh was conducting a study on state response to violence against women. One approached Walsh directly and asked to be included. The other asked the organization if they could meet with her to share their story. Although they were informed that a researcher could not "help" their case, both families expressed the hope that sharing their experiences might help to improve the justice system. These families provided us with the rare opportunity to reveal obstacles in the justice system through their own words and experiences as they were going through the process.

\section{FAMILIES IN MOURNING AND THE GENDERED DIMENSIONS of DeAdly Abuse}

These two families each suffered the murder of a child. María and Rosa both died young - each under 25 years old. María grew up in a working-class family living in a small rural town. During the last moments of her life, she went to run an errand in her neighborhood, but later appeared in the street injured and bleeding. She had been sexually assaulted so brutally that her internal injuries ended up being fatal. The preponderance of evidence pointed to a neighbor as the perpetrator. Her sexual assault conforms in many ways to a broader pattern of sexualized torture and killings that have occurred in Guatemala (Carey and Torres 2010).

Rosa grew up in a middle-class family living near Guatemala City, and was married. Soon after the wedding, her husband began exhibiting controlling and erratic behavior. She reported this to the police and even attempted to leave, but her husband managed to coerce her into returning. The husband's pattern of coercive control conforms to those that have become a part of life in a society that normalizes violence against women in intimate relationships and trivializes "private" violence (Hume 2009; Menjívar 2011). Rosa's husband isolated her from her family, and then she disappeared one night as friends and family called to try to reach her. Her body was later found in another part of the city, beaten with such extreme force that she was nearly unrecognizable. Within a short time of being married, her husband became the prime suspect in her murder. Against all odds, María's and Rosa's families both decided to work through the legal system to pursue justice for their daughters. ${ }^{3}$ 


\section{The Legal Toll OF OVERCOMING FeAR}

The need to overcome fear of reporting with the absence of witness protection in a context of impunity and violence is an intangible burden, but no less serious an obstacle to achieving justice in Guatemala, and thus a legal toll. Women are disproportionately likely to become victims at the hands of male perpetrators, who are usually more economically and socially powerful than they are. Women are unlikely to report threats or violence against them, due, among other things, to a lack of protection or an anticipation of retaliation, to the informal institution that "everyone knows" that the justice system will be unresponsive to their claims. Silence can also be driven by a habit of keeping quiet in a world that coercively demands women's compliance, sacrifice, and enduring violence (Menjívar 2011). This even extends beyond their death, when widespread gender discrimination and symbolic violence in the form of depreciation of women's lives means that families of murdered women must fight just to get cases taken seriously.

It is commonly said that Guatemalans are "very silent" (see Wilkinson 2004) and unwilling to report or share information about crime. One person who worked in the justice system blamed this hesitancy on a "culture that does not report crime" (Interview 2014). However, with a lack of witness protection and a long history of fear inspired by state repression and normalized institutional unresponsiveness and violence (Green 1999; Levenson 2013; Menjívar 2011; Nelson 1999; Wilkinson 2004), people are naturally hesitant to report crimes.

During Guatemala's three decades of civil war and state terror, the government created networks of informants and conscripted community members into the army in order to disrupt traditional community ties and sabotage potential organizing efforts against the government (Menjívar and Rodríguez 2005). During this time, the police were used as a repressive force, responsible for the surveillance and capture of people suspected of sympathizing with the opposition (Sanford 2004; REHMI 1999). These tactics undermined trust in state authorities and turned neighbors against neighbors, as fear of being informed on obstructed friendships and family relations.

Scholars have observed that this fear, entwined with state repression, exploitation, and control of the majority of the population, has persisted and evolved over time (Adams 2011). As Green (1999) argues, fear is so embedded in Guatemala, particularly among the indigenous, that it has become a way of life. The "culture" of obedience and silence it has produced amounts to a collective amnesia (Wilkinson 2004). In such a context, how can anyone be expected to report crime when there is no guarantee of protection from retaliation?

When witnesses are threatened, victims should be able to rely on police as a first line of defense. However, the Guatemalan police and other state agencies lack the will or capacity to protect those who report crimes or threats. Beyond their wartime activities in state-sponsored surveillance, police are widely known to be involved in corruption and integrated into criminal networks (Boche 2015; Peacock and Beltrán 2003). Amnesty International (2002) describes how the police 
and the military, traditional sectors serving the oligarchy, and common criminals collude to control illegal activities that include arms trafficking, money laundering, car theft rings, and kidnapping for ransom. Corruption is ongoing and widespread, permeating every level of government. Guatemala's former president Pérez Molina and Vice President Roxana Baldetti were both forced to resign in 2015 due to corruption charges (Dada 2015).

Reporting crime can put the victims at high risk of retaliation (World Bank 2010). If victims and their families had financial resources or social capital and could activate their social networks, they could better protect themselves. However, very few people in Guatemala have much of either. It takes an extraordinary amount of money and social capital to keep the location of families concealed in Guatemala, which would normally require periodic moving in this relatively small country where hiding places are easily discovered. Also, most people's jobs and livelihood are tied to their neighborhoods or the cities in which they live, especially those of working-class families. Witnesses are particularly vulnerable around the times they are required to show up at court hearings to process cases, when perpetrators will be able to predict their exact location.

María's family found evidence after her death that she had been subjected to humiliation and threats by a male neighbor. María stayed silent about this, never revealing it even to her family. Her family described how the neighborhood turned against them once they reported that their daughter's death was a murder.

And now, for all of [our neighbors], we are the bad guys. Everybody turned against us. We never had problems [in the neighborhood] until now. Before [our daughter was killed], people would talk with us. They would look to us for many things and chat about anything and say "Good afternoon." But we never thought ... we never thought this situation would happen. We had very close neighbors, close, close. (Interview, María's Family 2014)

María's family members observed that all their nearby neighbors became their enemies because they were asking to punish those responsible for their daughter's death. Neighbors began brandishing guns outside the house. When the family began to report threats to the police, they were slow to react at first, but were more responsive once the family asked for a restraining order and the public ministry made the police aware of the seriousness of these threats.

However, threats to their lives escalated after police detained a neighbor, the primary murder suspect. Due to these threats, María's family members made the necessary but difficult decision to leave their jobs and home and everything else to go into hiding. However, within a couple of months, some outsiders (who were presumably friends or family of the murder suspect) began asking around for them. The family left this hiding place and fled again. The father reported that there were many days when they went hungry. Some days he made the equivalent of $\$ 13$ and others $\$ 6.50$, not enough to sustain the family. The family recalled that the police failed to adequately respond to their requests for protection until they filed a claim (denuncia) with the public prosecutor's office. 
Interviewer: About the threats, have you been in contact with the police or the public prosecutor's office?

Family: Yes.... The public prosecutor's office asked the police for restraining orders for the family. We had to call the police many times for them to come because men were walking around [outside] the house. One time we had to call around midnight. Another time we had to ask for them to come in the evening to look inside the house because men had gone inside the house. Well, they did not provide us with help.

Interviewer: When you called the police, did they arrive quickly or slowly? Did they help protect you?

Family: Well, at the very beginning, they did not arrive quickly. They were quick when they found out what was going on. Before, it was only we who had asked. But afterward, we had to ask the public prosecutor's office so that they [would enforce the restraining order]. After that, they came, but before this, no.

Interviewer: [To clarify], what made the difference? The claim?

Family: The claim. Because it seems that when there is a paper where something is written, it is as if ... it has more, [we] don't know ... they are afraid not to do things or something like that. It is this way because ... so many things have happened, many times due to negligence of the authorities that have done things that they have had to lament many times.

In this account, María's family reveals that the police were not responsive until the court obliged them to be. Meanwhile, the family endured threats to their lives. Even after the claim was filed and the police responded when called, the family was unable to obtain adequate protection, and this forced them to flee. This is an example of the punitive consequences when families try to process cases through the justice system. Families can easily foresee, as well, that they will remain in danger even if they move to a different location, as the same conditions, practices, and system of impunity operate throughout Guatemala. The legal toll of overcoming fears of reporting is exorbitant, particularly for the poor and vulnerable.

A revealing example of widespread fear of reporting is that the public prosecutor's office told María's family that it knew of many cases of rape in María's neighborhood "but the people ... the people are silent." ${ }^{4}$ Silence is not the sign of a culture of unwillingness to report; it is an indicator that people have a reasonable fear of retaliation and awareness of the informal institution that the justice system will not protect them. María's family also shared the story of a friend whose daughter was raped and noted that in her case, the public prosecutor's office "did not do anything. So, these are situations in which you lose confidence in the authorities and the police." The family friend noted that the judge in their case was useless because he took the side of the criminals and left the victims abandoned.

There are also several examples throughout the experiences of Rosa's family that point to Guatemalans' fear of reporting crimes due to lack of protection for victims and witnesses, as well as responses that fail women in particular. Before she was mur- 
dered, Rosa attempted to leave her husband, but reported his behavior to the police only after years of life-threatening abuse. However, she was not encouraged to seek a restraining order. The family noted that when Rosa filed a police report and asked for a restraining order, the police told her just to call them if there was a problem. This exemplifies a broader pattern in Guatemala of police treating violence against women as something ordinary, not worthy of following through with concrete legal protections, which contributes to the normalization of violence in the lives of women through formal institutions. Furthermore, the family noted that calling the police without an order would be useless because it would take two hours for the police to arrive and, by that time, "you would already be dead" (Interview, Family of Rosa 2014).

The family's account of the crime scene and subsequent funeral also reveals how vulnerable people are to potential threats from murderers. In Guatemala, threats need not be explicit because the widespread lawlessness and the informal institution of "knowing" that police will be indifferent to these crimes creates a de facto impunity that protects predators. In this context, Rosa's family was stricken by fear after the funeral when they discovered that an individual had been taking photos of the family without their permission. One family member described the situation.

After [the funeral], I found out that someone had been walking around taking photos. Logically, I don't know if it was an investigator, I don't know. There was [a person] walking around ... very surreptitiously taking photos of us ... so this began to scare all of us. Why? So, this is where people began to have a fear that we [were] being watched.

Another family member noted, "These are intimidations.... They could take a photo to say 'Look ... find this person and kill them,"' referring to the fact that it is easy to hire an assassin in Guatemala. The family worried that the suspected murderer might hire someone to kill them, as has happened in several cases. There is always concern in Guatemala that witnesses will be targeted, bought, or implicitly or explicitly threatened if they want to testify.

Rosa's family members expressed their views about witness protection in Guatemala and noted that, although there is a witness protection program, it is known for not protecting witnesses. They shared a story of one person who did get witness protection in the form of three nonuniformed police officers guarding the house, but the protected man was killed a month later. One family member said that, although witness protection exists in Guatemala, it was not offered to them, and the family feared retaliation.

[As for] witness protection, the only thing I have seen here is giving witness protection during the first declaration and not to reveal the face of the person who made the declaration or the name. However, I am sure that this person did not say to them: 'do you want someone to accompany you?' That is, they did not offer us anything as a family, and this is one of the reasons that we feel afraid. 
Lack of protection and persistent dismissal of violence against women by the police contributes to women's hesitancy to report their victimization. Fear operates in ways that are latent, as well as being an active obstacle to action. State failure to protect witnesses in Guatemala makes people afraid to report crimes or testify and, in turn, contributes to impunity. The toll of overcoming fear of retaliation for reporting and processing feminicide cases is extreme, and leaves injured parties even more vulnerable to threats and violence. This fear extends not only to murder cases but to other types of violence, including rape and domestic violence. Injured parties must overcome fear of retaliation as they seek justice. In an important way, this fear is rooted in a history of abuses, state repression, and terror such that it is now an obstacle to reporting crime.

\section{The Legal Toll OF TIME AND EFFORT}

A further injury to victims and their families after a crime has been committed is the burden of spending time monitoring the case to make sure everything that should be done is done and not falling through the cracks as a result of mismanagement, corruption, and lack of capacity or will. Processing a case takes time for victims and their families in any legal system. However, the burden placed on injured parties to get the work done that should be handled by the justice system is so great in Guatemala that it constitutes a legal toll. This is amplified by social class and gender, as the lives of vulnerable, poor women who are killed are given even less attention in investigations and prosecutions. This inattention is mitigated only for the small minority of aggrieved families who are able to find volunteer accompaniment and free legal assistance for their cases.

The time and effort that victims and their families must surrender or be refused passage through the justice system is tantamount to the state's outsourcing basic monitoring and investigative functions (and even basic policing functions) to the already injured and vulnerable. Families with few financial resources rarely make it very far in this process. Thus, most cases are put en la caja, a popular phrase referring to the typical legal outcome of cases: they are filed or boxed away and ignored. For families who do confront the system, the toll of time and effort for doing so is extraordinary, particularly in light of their other time demands. This is also how the state exerts its power on the poor or marginalized and how subordination and domination are reproduced (Auyero 2011). As for the poor, Secor $(2007,41)$ observes, "the state in everyday life provokes running around uselessly and waiting, and this ineffective ritual can best be short-circuited through the pulls of influence, status, or money." This is how a context of deep inequalities arising from structural, symbolic, and gender violence intersects with the toll of time, as it is the poor who are more likely to wait and spend time in government bureaucracies to obtain the services or justice they seek.

A typical situation in Guatemala is that cases, even murder cases, languish unless families or advocates have the resources to pressure state and nonstate insti- 
tutions to attend to them. María's family described their frustration with trying to get the public prosecutor's office to advance their case.

Family Member: On one occasion I had to go to the public prosecutor's office ... in order to denounce the investigator who was there, who had the case.

Interviewer: Why?

Family Member: I had to denounce the investigator because the case was not advancing. I said "Look gentlemen, forgive me but I feel, and as I see it, that my case has not advanced at all, that it is stagnant, it is stopped." The problem is that the same public prosecutor's office was telling the family that the [suspect] was about to be released [from preventive prison]. So I say, how is that possible?

According to María's family, the hearing for the case was postponed three times and prolonged over several months. One time, the defense lawyer did not even show up.

[In addition to] the problem with the public prosecutor's office that we had [noted earlier], they [also] did not have elements for the investigation. They did not have transportation. That is to say, first, they did not have sufficient personnel, people to go to the [crime scene] area to investigate and to take declarations. And second, they did not have transportation [meaning, they did not have cars available] to do it. This was making the case very slow.

María's family had to spend an entire day borrowing a car, paying for food for the police, and even having to drive the person suspected of murdering their daughter to the police station in order to be arrested.

The police did not have transportation.... The day that they captured [the suspect], I borrowed a car and paid for the gasoline.... I told [the police] where [the suspect] was...but a police officer told me, "but we don't have a car."

So María's father borrowed a car to drive the suspect to the police station. He had only the equivalent of $\$ 20$ and asked a friend to borrow $\$ 75$ to pay for gasoline and buy food for the police. The average 2014 income in Guatemala was US\$285 a month, much less for the poor (World Bank 2014, measuring GNI per capita). So $\$ 75$ was probably a third to a half of the family's income for the month, something that most impoverished families would be unable or unwilling to spend.

The police officers called their supervisor and told him that the father had a car and money for food, but they still hesitated. We may never know the particular reason for the police's hesitation in this case, but it conforms to a broader pattern of police treating women's lives as not worth protecting, their murders as unimportant, and putting the burden on victim's families for conducting basic police work (Sanford 2008).

The father insisted that they should go so that they could make the arrest, and that he had money for their food. When the police arrested the suspect, they put a sack over his head so that he could not see that it was the victim's father driving the 
car. This account is reminiscent of wartime police procedures (REHMI 1999; Sanford 2004). Even though it was reportedly done to separate the suspect so that he could not identify the victim's father as the driver, it still highlights how wartime standard operating procedures persist in everyday policing practices and structures.

Describing the situation, María's father said,

So, these are the authorities that we have. So, tell me: what can one hope for? What hope does one have? The justice system in Guatemala is so backward and not just this.... There is a lot of corruption, there are many offering money under the table so that cases do not continue, and I tell you that I, in a moment, when my case was stopped, I began to suspect that the public prosecutor's office was receiving money [e.g., bribes]. So, I said to my spouse, "We live in a country that is like this, what guarantees do we have? What guarantees? Sadly, none."

Because the justice system has so systematically ignored the killings of women in Guatemala, some nongovernmental organizations have stepped in to research the issue, and one directly assists families with their cases. One NGO reported that about 5 percent of families of women who have been murdered are provided with assistance and accompaniment. Therefore it was not the state but a local NGO that provided María's family with resources to pursue and prosecute her case. The family reported,

Now what did we find with [the organization]? They gave us economic support, moral support, support in every sense, psychological help, I don't know ... a ton of things! Thank God, we feel that ... if I were alone in the [court], without [the organization], I don't know how I would feel.

Even so, the assistance has not been sufficient to provide the family with enough help to keep them from fleeing and going hungry. So even in this "best case scenario" of the minority of families who get assistance, the help is insufficient to meet their most basic needs. Even the need for this kind of help indicates the lack of responsiveness of the police and justice system to complaints from the poor or in cases of violence against women.

María's family conveyed their commitment to work through the justice system. However, in Guatemala, it is perhaps easier to take justice into one's own hands (Godoy 2006). Vigilante groups have emerged in Guatemala to claim that they are taking the place of a broken justice system and killing suspected murderers. The family recognizes that pursuing justice through the justice system is the right thing to do, but they have suffered the tolls of time and effort, even to make the initial arrest. Compounding the injustices they have already suffered, the burden of spending so much time and effort just to do what should be straightforward policing is also an emotional drain. The father recounted his suffering after making the case public.

This day, I left my house around 7 A.M. and returned around 7 P.M., but I was [feeling sick]. And sometimes I say, "Yes, I go around this way [feeling bad] and do no harm [to the suspect], now, yes, this could make one violent...." I said to my spouse, "Truly, the right path is to ask the authorities to do justice." 
Rosa's family also knows that in Guatemala results are only obtained by pressuring authorities. However, the same oppressive conditions of poverty make those who most need attention to their cases least able to provide the necessary pressure to obtain it. Even Rosa's middle-class family could hardly afford the time away from work and other family obligations to try to keep their case from stalling out. During the two weeks when Walsh followed this family in their dealings with the justice system, they went to talk with at least four different state and nonstate agencies, spread across Guatemala City, multiple times. These family members traveled from one to three hours to the city center to oversee the case, to make sure that it was being processed and properly monitored. The poor are too busy working to survive to be able to afford the typical two-hour roundtrip to downtown Guatemala City on public transportation. Rosa's family lamented the necessity of this time- and energy-consuming activity.

Family Member 1: I would like to tell you something that happened to me. One time [someone had gunmen looking for me and threatened me over a property dispute]. So I got recognition [from the authorities] ... but it was because of friendship. I begged Congress and everything. This is the way it works! Because [I went where they make the rules]. But the poor people that are outside [the city and justice system], and they beg, and they beg, and they beg [for help].

Family Member 2: They don't pay any attention to them.

Family Member 1: So [you have to come] here, to the Congressional Human Rights Commission [Comisión de Derechos Humanos del Congreso], ta ta ta [to do this and do that], and have to be present on this day, ta ta ta. But what do you think is the [problem here], me? It is sad to accept this.

Rosa's family continued discussing the toll extracted from their lives of having to "make the rounds" asking for help from various state agencies with the case of their murdered family member. They noted that people have to go and stay in the city center in Guatemala City in order to be near the various state agencies where they have to ask for help. They lamented the time wasted on this, begging people in the various agencies to help, and if the family members are not from the city, they have to make arrangements to sleep in the city. They said, "This is not life," and commented that in this context, individuals do not have freedom. Judging from the reactions of many individuals we met in the justice system and human rights organizations, people perceived Rosa's case as something unexceptional and unimportant, just another woman who had been murdered by her husband. This is how the normalization of violence in the lives of women permeates the justice system; in life and death they are devalued.

In addition to obstacles in the process of seeking justice and the efforts on the part of the families, there were also serious deficiencies in the investigation process. In addition to the toll of time and effort, aggrieved families are ultimately responsible for monitoring and providing technical assistance to the investigation. Rosa's family member describes how an informal declaration on the suspected murderer's background was provided, but no one from the police or the prosecutor's office fol- 
lowed up on this or asked to formalize the declaration. As the family member explained, this was problematic because the murder suspect had a history of abusing the victim. This declaration would have provided further evidence for considering the aggressor a suspect.

[T]his is like an antecedent for how things arrived at this point. But what they told me is that all of the testimony that I have, to some extent, was not necessary or was not valid because what we are trying here is homicide. "We encapsulate this case, violence against women is going to be something else," but really no, for me this emerges from the same hand [viene de la misma mano, an expression meaning that the same thing that caused the past abuse also caused the murder].... But this is the way they painted it, that since I was not a witness at the scene of the crime and I am not a witness who saw the killing directly, that my testimony was not necessary. It is as if they did not want to put together the history. They were simply focusing on two days [before the discovery of the body] and not on the five preceding years.... So I think that this is an error, because with so few things that happened in two days, you could run the risk that there is not much evidence and that they [would] dismiss more than half of it. Proceeding as if [these antecedents] were [not part of the evidence], we remained without evidence to demonstrate that the aggressor was guilty.

The failure to take formal statements about the husband's prior history of abuse reveals a lack of awareness of the gendered dynamics of killings of women involving an intimate partner (so it can be reflected in law) and the normalization of violence in a union (Menjívar 2016). Murdering a spouse is often the final stage in a longstanding pattern of coercive control and abuse over the course of a relationship (Hume 2009; Menjívar 2011). Therefore, it is legally relevant to understand this history of abuse in order to establish a motive, among other things. Investigating only the events two days before the murder precludes an understanding of how abuse can progress over time, ultimately culminating in feminicide.

Both families observed a multitude of errors on the part of the justice system, but much of the time they were powerless to do the necessary work that might make the investigation more effective. Even in paying the many tolls of time and effort in monitoring botched investigation procedures, they were unable to have their cases effectively investigated. Without competent policing or prosecution, these families routinely had to stand by and grieve for the process they observed.

\section{Discussion AND CONCLUSIONS}

What explains such persistent gaps between the law on the books and the "living law" regarding feminicide in Guatemala? The social, economic, and legal context in Guatemala and many developing countries around the world includes persistent structural violence, profound inequality, corruption, and the normalization of violence against women. This context imposes legal tolls on victims and their families attempting to utilize the justice system. Through these two cases, this article has 
demonstrated how the tolls of fear and time that are imposed on victims and their families can contribute to impunity in a failing "law in between" (Jenness and Grattet 2005), that is, the justice system and those in charge of implementing laws. These tolls are exacerbated by a context of deep inequalities along gender and social class lines that make most people unable to pay these tolls_-and paying them is no guarantee of a desirable outcome.

The cases of María and Rosa demonstrate a wide range of obstacles to justice for families of victims of feminicide in Guatemala. We draw on Brinks's 2008 concept of legal tolls or penalties imposed on families when they attempt to navigate a broken and corrupt justice system to shed light on the mechanisms that sustain impunity and lack of enforcement of the law. In analyzing these cases, we identify two tolls - the toll of fear and the toll of time and effort- that help explain the persistent gap between the law in the books and reality in Guatemala in cases of feminicide. We also demonstrate that both class and gender inequality contribute to the existence of legal tolls. When less powerful, poor women are murdered, more powerful perpetrators can derail cases by many means, including threats and bribes. We refine the conceptual tool of tolls by adding the important intersection of gender to account for how poor women and their families experience bureaucracies and the justice system.

Despite legal advances on paper, justice system officials consistently follow informal institutional rules of ignoring cases and botching investigations, unless (and even if) there is pressure to attend to them. This is tied to more general attitudes about the normalization of gender inequality and violence in women's lives in a society so unequal that it devalues the lives of women and the poor. Poor women have multiple obstacles to overcome. The toll of overcoming fear due to lack of witness protection means that many victims must decide between pursuing either justice or safety from retaliation. For families with few resources (either financial or social capital), staying muy callado, or very silent, seems to be the rational option, particularly given Guatemala's history of state terror and repression and an institutional structure that has remained in place even after the official end of the civil war in 1996. In this context, corruption within the justice system has become an informal institution and it is "common knowledge" that it will not function, thus subverting the formal justice system (O’Donnell 2006).

In Guatemala, fear has become a "way of life" that produces obedience and silence (Green 1999; Wilkinson 2004), and the justice system now requires overcoming it in order to navigate its labyrinth. The toll of time and effort forces most families to abandon the process, especially if they are poor and would have to make a choice between pursuing justice or working to put food on the table. Waiting time is a significant element imposed on the lives of the poor in their experience of bureaucracies and state power in contexts around the world (see Auyero 2011; Secor 2007).

Similarly, the challenges surrounding the implementation of Guatemala's feminicide law have implications for women's rights on a global scale. A situation of impunity for violence against women exists in other parts of Latin America as well, such as El Salvador, Honduras, and Mexico (e.g., Fregoso and Bejarano 2010; 
Gaspar de Alba and Guzmán 2010; Morales and Bejarano 2009; Morales 2011; Staudt 2008; Wright 2006, 2011); and in other regions, such as Africa, Asia, and the Middle East (e.g., Behl 2014; Eisenberg 2011; Medie 2013; Merry 2006). Beyond our contribution to social science, we hope that exposing the fractures and gaps in the justice system in countries such as Guatemala also exposes the dynamics of impunity in other countries where gender inequalities permeate state authorities' cognitive frames and assessments, leading to the mishandling of murder cases and mistreatment of victims.

\section{Appendix: Violence Against Women Laws IN GUATEMALA}

\section{The Law Against Femicide and \\ Other Forms of Violence Against Women \\ Law 22-2008, passed May 2, 2008}

\section{General Description}

The law creates new crimes addressing violence against women. Physical, sexual, and psychological (includes family relationships, marriage, civil law unions, boyfriends, working partners, acquaintances, suitors, as part of a group ritual, or because of a misogynist behavior).

\section{Definitions and Penalties for Criminal Acts}

- Physical or sexual violence: 5-12 years in prison

- Psychological violence: 5-8 years

- Economic violence: restrictions on disposing of one's own property, forced signature on documents that affect property or liberate an aggressor from responsibilities, extortion denying economic support, infliction of violence in order to control income. $5-8$ years

- Femicide: to murder a woman because of her condition as woman (in a relationship of marriage or not; including dating partners, friendship, business, and work; as part of a group ritual; or because of a misogynist behavior). 25-50 years

\section{Implementation Mechanisms and Responsibilities}

- The National Coordinator of Intrafamiliar Violence and Violence Against Women (CONAPREVI) is in charge of policies and public programs

- The Presidential Secretariat of Women advices policies regarding women's development

- The District Attorney's Office on crimes against the life and physical integrity of women has prosecution functions

- The Secretariat Against Sexual Violence, Exploitation, and Human Trafficking, which belongs to the vice presidency, has the function of advising other institutions

Source for description of the law: Procuraduría General 2015. 


\section{The Law to Prevent, Punish, and Eradicate Intrafamiliar Violence Law $\mathbf{N}^{\circ}$ 97-1996, passed November 28, 1996}

\section{General Description}

- The law addresses violence in general in a family structure, marriage, or civil law marriage, even after the dissolution of the relationship, and people who have had children together. The purpose of the instrument is to create protective measures (i.e., restraining orders) that could be enforced from one to six months.

\section{Implementation Mechanisms and Responsibilities}

- Complaints may be filed at the District's Attorney's Office (Ministerio Público), Women's Affairs Office; Procuraduría General de la República, Section for the Protection of Human Rights of Women; National Police; Family Courthouses; Public legal aid services (Bufetes populares); Human Rights Office Ombudsman (Procuraduría de Derechos Humanos)

- All these agencies have 24 hours to refer the complaint to either a family courthouse or a criminal one depending on the case

Source for description of the law: Harvard School of Public Health 2015. Decreto numero 97-1996. Ley para prevenir, sancionar y erradicar la violencia intrafamiliar.

http://www.hsph.harvard.edu/population/domesticviolence/guatemala.dv.96.pdf. Accessed May 11, 2015.

\section{NoTES}

We are grateful to Victoria Sanford for her feedback on early drafts of this work. We are also thankful for very helpful comments from Daniel Brinks, Carlos Mendoza, members of the Guatemala Scholars Network, four anonymous reviewers, and the journal editors. We thank the study participants in Guatemala for generously sharing their time, personal stories, and knowledge, as well as several kindhearted people with whom we have shared homes, meals, and wonderful conversations while on fieldwork. Walsh acknowledges valuable support through an American Association for University Women American Fellowship.

1. Departments are subnational units in Guatemala, as states are subnational units in the United States. The departments with femicide courts are Petén, Quiche, San Marcos, Huehuetenango, Solola, Coban, Chiquimula, and Isabal.

2. The interviewee estimated that plaintiffs in less than 5 percent of murder cases are able to access accompaniment services (which help process cases, in addition to the public prosecutor's office).

3. The names María and Rosa are pseudonyms to maintain the confidentiality of the families. Some minor identifying details have been excluded or modified slightly for the same reason. For the remainder of this article, interviewees will be referred to by their relationship to María and Rosa.

4. In Spanish, muchas violaciones, pero la gente se ... la gente se calla. 


\section{REFERENCES}

Adams, Richard. 2011 Accustomed to Be Obedient. In The Guatemala Reader: History, Culture, Politics, ed. Greg Grandin. Durham: Duke University Press. 133-37.

Amnesty International. 2002. Guatemala's Lethal Legacy: Past Impunity and Renewed Human Rights Violations. Human rights report. February 28. London: Amnesty International. https:/www.amnesty.org/en/documents/AMR34/001/2002/en/ Accessed September 18, 2016.

Arbuckle, Anne N. 1996. The Condom Crisis: An Application of Feminist Legal Theory to AIDS Prevention in African Women. Indiana Journal of Global Legal Studies 3, 2: 413- 55.

Auyero, Javier. 2011. Patients of the State: An Ethnographic Account of Poor People's Waiting. Latin American Research Review 46, 1: 5-29.

Behl, Natasha. 2014. Situated Citizenship: Understanding Sikh Citizenship Through Women's Exclusion. Politics, Groups, and Identities 2, 33: 386-401.

Boche, Evelyn. 2015. Trabajadores del Ministerio Público filtraban información a redes criminales. El Periódico (Guatemala City), May 11. http://elperiodico.com.gt/2015/11/05/ pais/trabajadores-del-mp-filtraban-informacion-a-redes-criminales. Accessed January 31, 2016.

Brinks, Daniel M. 2008. The Judicial Response to Killings in Latin America: Inequality and the Rule of Law. New York: Cambridge University Press. . 2012. A Tale of Two Cities: The Judiciary and the Rule of Law in Latin America. In The Routledge Handbook of Latin American Politics, ed. Peter R. Kingstone and Deborah J. Yashar. New York: Routledge. 61-75.

Carey, David, Jr., and M. Gabriela Torres. 2010. Precursors to Femicide: Guatemalan Women in a Vortex of Violence. Latin American Research Review 45, 3: 142-65.

Dada, Carlos. 2015. Corruption Charges Turn Guatemala Upside Down. New Yorker, September 4. http://www.newyorker.com/news/news-desk/corruption-charges-turnguatemala-upside-down. Accessed January 31, 2016.

Dietrich, Hasse, and Ketevan Kvatskhava. 2002. Rule of Law Assistance Impact Assessment. Management Systems International, June 17. USAIS Contract: AEP-1-00-00-00024-00, Task Order No. 4.

Eisenberg, Ann Marie. 2011. Law on the Books vs. Law in Action: Under-Enforcement of Morocco's Reformed 2004 Family Law, the Moudawana. Cornell International Law Journal 44, 3: 693-728.

Ellickson, Robert C. 1991. Order Without Law: How Neighbors Settle Disputes. Cambridge: Harvard University Press.

Farmer, Paul. 2004. An Anthropology of Structural Violence. Current Anthropology 45, 33: 305-25.

Fregoso, Rosa-Linda, and Cynthia Bejarano. 2010. Terrorizing Women: Feminicide in the Americas. Durham: Duke University Press.

Galtung, Johan. 1969. Violence, Peace, and Peace Research. Journal of Peace Research 6, 33 : 167-91.

Gasman, Nadine, and Gabriela A. Álvarez. 2016. Gender: Violence Against Women. Americas Quarterly. http://www.americasquarterly.org/node/1930. Accessed May 19, 2016.

Gaspar de Alba, Alicia, and Georgina Guzmán. 2010. Making a Killing: Femicide, Free Trade, and La Frontera. Austin: University of Texas Press.

George, Alexander L., and Andrew Bennett. 2005. Case Studies and Theory Development in the Social Sciences. Cambridge: MIT Press. 
Gerring, John. 2007. Case Study Research: Principles and Practices. Cambridge: Cambridge University Press.

Godoy, Angelina Snodgrass. 2006. Popular Injustice: Violence, Community, and Law in Latin America. Stanford: Stanford University Press.

Green, Linda. 1999. Fear as a Way of Life: Mayan Widows in Rural Guatemala. New York: Columbia University Press.

Harvard School of Public Health. 2015. Decreto no. 97-1996. Ley para prevenir, sancionar y erradicar la violencia intrafamiliar. http://www.hsph.harvard.edu/population/domestic violence/guatemala.dv.96.pdf. Accessed May 11, 2015.

Helmke, Gretchen, and Steven Levitsky, eds. 2006. Informal Institutions and Democracy: Lessons from Latin America. Baltimore: John Hopkins University Press.

Htun, Mala, and Timothy J. Power. 2006. Gender, Parties, and Support for Equal Rights in the Brazilian Congress. Latin American Politics and Society 48, 4 (Winter): 83104.

Hume, Mo. 2009. The Politics of Violence: Gender, Conflict and Community in El Salvador. Malden: Wiley.

International Monetary Fund (IMF). 2014. Growth in Latin America and the Caribbean Slows Further. IMF Survey, October 10. Washington, DC: IMF.

Jenness, Valerie, and Ryken Grattet. 2005. The Law-In-Between: The Effects of Organizational Perviousness on the Policing of Hate Crime. Social Problems 52, 3: 337-59.

Kent, Allison D. 2007. Custody, Maintenance, and Succession: The Internalization of Women's and Children's Rights Under Customary Law in Africa. Michigan Journal of International Law 28: 507, 519-20.

Lagarde, Marcela. 2006. Del femicidio al feminicidio. In Desde el jardin de Freud. Revista de psicoanálisis no. 6. Bogotá: Universidad Nacional de Colombia. 216-25.

2 2010. Preface: Feminist Keys for Understanding Feminicide: Theoretical, Political, and Legal Construction. In Fregoso and Bejarano 2010. xi-xxv.

Levenson, Deborah T. 2013. Adiós Niño: The Gangs of Guatemala City and the Politics of Death. Durham: Duke University Press.

Liaw, H. Ra. 2008. Women's Land Rights in Rural China: Transforming Existing Laws into a Source of Property Rights. Pacific Rim Law and Policy Journal 17: 237-38.

Macaulay, Stewart. 2005. The New Versus the Old Legal Realism: “Things Ain't What They Used to Be." Wisconsin Law Review 2: 365-403.

McCarthy, Joe. 2015. The Femicide Crisis in Latin America Is Too Deep for Laws Alone to Address. Global Citizen, August 15. https://www.globalcitizen.org/en/content/thefemicide-crisis-in-latin-america-is-too-deep-f. Accessed May 19, 2016.

Medie, Peace. 2013. Fighting Gender-Based Violence: The Women's Movement and the Enforcement of Rape Law in Liberia. African Affairs 112, 448: 377-97.

Menjívar, Cecilia. 2011. Enduring Violence: Ladina Women's Lives in Guatemala. Berkeley: University of California Press.

- 2016. Normalizing Suffering, Robadas, and Marital Unions Among Ladinas in Eastern Guatemala. In Marital Rape: Consent, Marriage, and Social Change in Global Context, ed. Kersti Yllö and M. Gabriela Torres. New York: Oxford University Press. 7585.

Menjívar, Cecilia, and Nestor P. Rodríguez, eds. 2005. When States Kill: Latin America, the U.S., and Technologies of Terror. Austin: University of Texas Press.

Merry, Sally Engle. 2006. Human Rights and Gender Violence: Translating International Law into Local Justice. Chicago: University of Chicago Press. 
MESECVI (Follow-up Mechanism to the Belém do Pará Convention). 2014. Second Follow-Up Report of the Recommendations of the Committee of Experts of the MESECVI. October. Washington, DC: Organization of American States/MESECVI.

Morales, María Cristina, and Cynthia Bejarano. 2009. Transnational Sexual and Gendered Violence: An Application of Border Sexual Conquest at a Mexico-U.S. Border. Global Networks 9, 3: 420-39.

Morales, Tacuazina. 2011. Honduras: escalada de feminicidios. SEMLAC (News Service on Women in Latin America and the Caribbean). March 16. http://amecopress.net/spip. php?article6376. Accessed September 18, 2016.

Moser, Robert G. 2001. Unexpected Outcomes: Electoral Systems, Political Parties, and Representation in Russia. Pittsburgh: University of Pittsburgh Press.

Nelson, Diane M. 1999. A Finger in the Wound: Body Politics in Quincentennial Guatemala. Berkeley: University of California Press.

O’Donnell, Guillermo. 2004. Why the Rule of Law Matters. Journal of Democracy 15, 4: 32 46.

. 2006. On Informal Institutions, Once Again. In Helmke and Levitsky 2006. 28590.

Peacock, Susan C., and Adriana Beltrán. 2003. Hidden Powers: Illegal Armed Groups in Post-Conflict Guatemala and the Forces Behind Them. Report. September 4. Washington, DC: Washington Office on Latin America. https://www.wola.org/analysis/hiddenpowers-in-post-conflict-guatemala

Portenier, Giselle. 2007. Killer's Paradise. Film. Produced by the National Film Board of Canada. Brooklyn: Icarus Films.

Prieto-Carrón, Marina, Marilyn Thomson, and Mandy Macdonald. 2007. No More Killings! Women Respond to Feminicides in Central America. Gender and Development. 15, 1: $25-40$.

Procuraduría General de la Nación de Guatemala. 2015. Ley contra el femicidio y otras formas de violencia contra la mujer. Decreto 22-2008. http://www.pgn.gob.gt/leycontra-el-femicidio-y-otras-formas-de-violencia-contra-la-mujer-decreto-22-2008. Accessed May 11, 2015.

Radford, Jill, and Diana Russell. 1992. Femicide: The Politics of Woman Killing. New York: Twayne.

Recovery of Historical Memory Project (REHMI). 1999. Guatemala Never Again! Official report of the Human Rights Office, Archdiocese of Guatemala. Maryknoll, NY: Orbis.

Sanford, Victoria. 2004. Buried Secrets: Truth and Human Rights in Guatemala. New York: Palgrave Macmillan.

2008. From Genocide to Feminicide: Impunity and Human Rights in Twenty-FirstCentury Guatemala. Journal of Human Rights 7: 104-22.

Secor, Anna J. 2007. Between Longing and Despair: State, Space and Subjectivity in Turkey. Environment and Planning D: Society and Space 25, 1:33-52.

Staudt, Kathleen. 2008. Violence and Activism at the Border: Gender, Fear, and Everyday Life in Ciudad Juárez. Austin: University of Texas Press.

Torres, M. Gabriela. 2005. Bloody Deeds/Hechos Sangrientos: Reading Guatemala's Record of Political Violence in Cadaver Reports. In Menjívar and Rodríguez 2005. 143-69.

United Nations Development Program (UNDP). 2013. Gender Inequality Index. Human Development Reports. http://hdr.undp.org/en/content/gender-inequality-index Accessed September 18, 2016. 
U.S. Department of State. Bureau of Democracy, Human Rights, and Labor. 2012. Country Reports on Human Rights Practices for 2012: Guatemala. Washington, DC: Department of State.

Volk, Steven S., and Marian E. Schlotterbeck. 2007. Gender, Order, and Femicide: Reading the Popular Culture of Murder in Ciudad Juárez. Aztlán: A Journal of Chicano Studies 32, 1: 53-82.

Walsh, Shannon Drysdale. 2008. Engendering Justice: Constructing Institutions to Address Violence Against Women. Studies in Social Justice. 2, 1: 48-66.

Walsh, Shannon Drysdale, and Cecilia Menjívar. 2016. Impunity and Multisided Violence in the Lives of Women in Latin America: El Salvador in Comparative Perspective. Current Sociology 64, 4 (July): 586-602. First published April 18.

Wilkinson, Daniel. 2004. Silence on the Mountain: Stories of Terror, Betrayal, and Forgetting in Guatemala. Durham: Duke University Press.

World Bank. 2014. Poverty and Equity: Data for Guatemala 2014. http://povertydata.worldbank.org/poverty/country/GTM. Accessed January 18, 2016.

Central American Unit. 2010. Crime and Violence in Central America, vol. 2. Report No. 56781-LAC. September. Washington, DC: World Bank.

Wright, Melissa. 2006. Public Women, Profit, and Femicide in Northern Mexico. South Atlantic Quarterly 105: 681-98.

. 2011. Necropolitics, Narcopolitics, and Femicide: Gendered Violence on the Mexico-U.S. Border. Signs: Journal of Women in Culture and Society 36, 3: 707-31. 